\title{
Developing and Proposing Zakat Management System: A Case of the Malakand District, Pakistan
}

\author{
Suhail Ahmad \\ Sarhad University of Science \& Information Technology, Peshawar Pakistan
}

\begin{abstract}
Zakat plays a vital role in the socio-economic development of a country. With zakat, the poor community is facilitated their food, safety, nutrition, sanitation, education, and other necessities. This study focuses on the role and current practice of zakat in the Malakand district of Khyber Pakhtunkhwa, Pakistan. This paper also develops and proposes a model for efficient management of zakat there. In doing so, this study interviews a sample of thirty respondents. A list of ten questions is constructed during the interviews using the local language, which is Urdu. The current practice of zakat in the region is explored, and further recommendation is captured for better practice of zakat management. For this, the study proposes an ideal model of the zakat management system, which can also be adopted by other countries. The discussion of this study is limited to the district of Khyber Pakhtunkhwa of Pakistan.
\end{abstract}

Keywords: Zakat, poverty alleviation, socio-economic development, ideal management, Pakistan

\section{INTRODUCTION}

Zakat is one of the main pillars of Islam, which is the 5th number of the Islamic principle, and it is compulsory by the Almighty Allah for Muslims. The institution of zakat is settled first by the Muslims community in the right way (Kaslam, 2009). Zakat is the main tool for poverty eradication by helping needy people (Lubis M., 2011). Zakat is from Arabic, which means to purify (Zayas, 2003). Zakat can be of two types. The first is Zakat Fitr, and the second is Zakat on wealth. Zakat Fitr is paid by Muslims every year after the holy month of Fasting. Meanwhile, Zakat of wealth is to be paid by Muslims who have met nishab. Such zakat is charged on business, savings, income, gold and silver, poultry, fruits, and grains (Lubis M., 2011).
The receiver of zakat is mentioned in the Holy Book of Quran in verses 60 of Surah Al Tawabah, which are; the needy, the poor, the Amil (who collects zakat), the Muallaf (who revert to Islam), Slave, person who have debts, person who are in the way of Allah, and the travelling people.

Zakat is distributed to the impoverished community for not only fulfilling their necessities but also for imparting their share in the community and economic development. In Malaysia, Sarif \& Kamri (2009) studied the use of Zakat for the sparse population to enrich their capabilities, skills, and other activities. Such distribution has enabled them to be permanently independent financially (Sarif \& Kamri, 2009). 
The role of Zakat in the socioeconomic development of a country is significant. A study proposed a model for zakat, waqf, and Islamic microfinance and their role in alleviating poverty in the society, which has resulted in the socioeconomic development of a country (Hassan \& Ashraf, 2010). Zakat is one of the main tools for poverty alleviation as well as for inequality in the society, and maintain social justice and harmony in the community, which leads to the socioeconomic development of Pakistan (Farooq, 2008; Siddiqui, 2009).

Most of the scholars are of the view that the problems of poverty and socio-economic injustice is reflected in most of the Muslims countries because of the non-practicing of the true sense of Zakat, the policies, and strategies for achieving the essence of zakat in full spirit laid down by the Shariah and Islamic Principles (Barizah, Rahim, \& Rahman, 2007).

This study elaborates and sees the way Zakat plays a role in socioeconomic development in the Malakand District of Khyber Pakhtunkhwa, Pakistan. It is interesting to study the Malakand district as it is a rural area with a large number of poor people. Even such zakat institutions exist there, but their role is below satisfactory level. Moreover, the district also suffers from the War and terror situation occurred from 2007 to 2011. That had resulted and snatched the necessities of the local people. Briefly, that is the reason to select this district.

\section{Objective of The Study}

The study has the purpose of developing and proposing an idea model for management of Zakat.

\section{LITERATURE REVIEW}

The main objective of Zakat is to attain socio-economic development and alleviate poverty in society ( $\mathrm{Al} \mathrm{Haq} \mathrm{\&}$ Wahab, 2017; Hati \& Aida, 2014). Zakat maintains to achieve the goals of social justice and reduce poverty through the enhancement of facilitates; like education, health, human development, and environmental aspects of society (Muliyaningsih, 2013). In Indonesia, the voluntary sector can enhance the facilities of zakat for achieving the community development goals in the shape of eradicating poverty, which results in the socio-economic development of the society (Alam, 2010).

Zakat can play its due role in the promotion and development of the economic and social well-being through better education, health, food, and nutrition facilities to the poor and needy individuals in the society. In Malaysia, zakat plays a vital role in the promotion and enhancement of educational facilities to the poor in the community. Also, zakat is not only distributed for the educational facilities, but also is aimed at the food and nutritional facilities to the individuals in Malaysia (Suprayitno, Aslam, \& Harun, 2017).

In Pakistan, Zakat plays a vital role in the socioeconomic well-being, notably for widows, orphans, and disabled people. The amount of zakat given in monthly basis and grant for disabilities(Toor \& Nasar, 2003).

A study was conducted in which investigated the Benazir income support program and zakat program in Pakistan. It is only on the implementation strategies of both the program in Pakistan. It is not a survey base or includes a proper analytical procedure and analyses of the respondent of the 
mustahik (zakat recipient) or the others (Khan \& Qutub, 2010).

A study was conducted in Peshawar to investigate the role of zakat and the problems faced by the local mustahik. It sampled eighty participants for interview sessions. The study found that the local mustahik has been facing issues in receiving the zakat. This shows the non-improvement of the socio-economic condition of the individuals of Peshawar. This study is problematic, however (Zeb \& Zaman, 2014).

From the literature review above; there is a lack of a comprehensive study of the subject domain in the Malakand district, Pakistan. This is the first study which elaborates the role of Zakat in the development of the social well-being of the local population of Malakand district.

Malakand district is $120 \mathrm{~km}$ away from the capital of the province, Peshawar. This district is vital due to its location. It connects the regions of Dir Lower, Dir Upper (formerly Dir States), with Peshawar and Chitral, and which leads to China; it also connects District Swat (formerly Swat State) to the Peshawar. Moreover, it consists of two Tehsils (Dargai and Batkhela). It has a total population of 720,295 . In which 304,112 is the population of Dargai Tehsil and 416,183 of the Batkhela Tehsil of Malakand District of Khyber Pakhtunkhwa of Pakistan (Statistics, 2017).

\section{RESEARCH METHODOLOGY}

This section describes the population, data collection, and data analyses of the study. The population of this study is the Malakand District of Khyber Pakhtunkhwa, Pakistan. The interview is conducted to the individuals of Malakand Districts from the two tehsils.
For the interview; the male and female households are considered.

\section{Inclusion Criteria}

This study only focused on Malakand districts, Pakistan. Both male and female household that bears all the responsibilities of their families in terms of food, safety, health, and education are considered for the study

\section{DATA ANALYSIS}

The interviews conducted in both the tehsils of Malakand district of Khyber Pakhtunkhwa. A total of ten questions are asked to the individuals and are recorded digitally. The interviews in Urdu and translated into English for further analysis. Twenty-eight participants are selected. The list of questions is as of Table 1.

When question one is asked, the participants ( $\mathrm{n}=15$ male \& 13 female) similarly respond;

"Zakat means the purity of wealth. It is a prescribed the amount of wealth, mandatory on Muslims to be given to the poor segment of society. Allah (Almighty) has defined eight heads in The Holy Book of Quran, whom zakat could be given".

As above, it is clear that the local people are aware of zakat. Similarly, the second question is asked to the interviewees ( $\mathrm{n}=17$ male \& 11 female). They answer;

"Of course, zakat plays a vital role in the upliftment of the poor in society and thus of the society as a whole. The oppressed and needy person gets the money by which they fulfill their needs in terms of 
food, nutrition, safety, health, education facilities, and other necessities of life. Thus, the circulation of wealth comes from the rich and wealthy persons, and the poor enjoy the opportunity of a happy life by receiving the zakat".

From the views of different male and female individual's in Malakand district, that zakat is a critical factor for the socio-economic development of a society in terms of providing various necessities of life, which enhanced their lifestyle and resulted in the shape of socio-economic development of the community.

Further, the answer to the question number third is as follows $(\mathrm{n}=19$ male \& 9 female);

"Current zakat system in the country is not satisfactory. The state and government have not given it a priority. It has organizational issues; there is no unified technique and procedures for its accumulation and distribution as required".

From the views of the individuals of the region, they think that the current zakat system needs to be modified and the government and organizations have promoted it to the required level in which the poor segment of the society can be maximum benefited from the zakat in the region.

In the interview session in tehsils of Malakand district, the answer to the question fourth is in the following $(\mathrm{n}=12$ male $\& 16$ female $)$ :

"In my perception; zakat is the backbone of the Islamic financial system. If it's properly managed, it can alleviate the poor segment of society from poverty. Moreover, circulation of wealth can be ensured, which is the sign of prosperity, and Islamic moral economy. A uniform class can be developed; peace and harmony can be attained if the gap between rich and poor is minimized".

It is clear from the views of the individual's, that zakat is the primary tool of poverty eradication from the society by filling the gap of the flow of wealth from rich to poor in the community.

The opinion of the participants ( $\mathrm{n}=10$ male \& 18 female) answering question fifth is as follows;

"Yes; the zakat is a suitable option for the socioeconomic development of a country by providing the wealth from the persons who has the nishab to the needy and poor community of the country, through which poor community can avail the basic needs and requirements for a better and prosperous life, which leads to socioeconomic development of a country"

Similarly, the interviewees ( $\mathrm{n}=21$ male \& 7 female) answering the question number sixth is;

"There is a lack of
transparency in the distribution
of zakat. Proper management
and distribution to the eligible
poor in all regions need
reforms. Giving the amount of
zakat to the relatives of the
presiding officer must be
checked".


The statement mentioned that in the region of Malakand district, the receiver of zakat facing problems in the management of zakat distribution because they favor their known and ignored the poor community.

Further, when the question number seventh is asked from the participants ( $\mathrm{n}=13$ male and 15 female), their responses;

"The zakat amount can
facilitate the individuals by
receiving from the wealthy
persons in their health and
education facilities for their
children. But in the case of
Malakand district, the case
may be not as much
satisfactory level as required.
The zakat management
organization in the District,
tehsil, and village council level
must be expedited, and proper
distribution of the right and
poor community can be
targeted and facilitated".

In case of the dowry and marriage ceremony of the girls and female of Malakand, zakat role according to their answers $(n=14$ male \& 14 female), as asked within question eighth as follows;

"Zakat can also facilitate the marriage expenses and the dowry of the poor girls and female of the society, but in case of Malakand district, the amount of zakat is not sufficient to fulfill their requirement because of the little amount received by them. The provincial government and department of awqaf required to provide the funds of zakat to the district level according to their population, which can be helpful for the proper distribution and fulfillment of their requirements".

The answer to question number ninth is as follows ( $\mathrm{n}=17$ male \& 11 female);

"The zakat can prosper the poor community of the society by receiving the zakat amount, which they can use for their basic requirements of life, includes food, safety \& housing, education, health, and similarly for the marriage expenses of their children, which resulting in the lifestyle improvements."

It is the view of individuals that the zakat improves and changes the lifestyle of the poor segment of the society if it adequately managed and distributed.

The replies of question number ten from the respondents $(\mathrm{n}=16$ male $\&$ 12 female) as follows;

"The current zakat system has a small impact. The state and government must supervise it. Collection of zakat and awareness among the citizens is required. Moreover, those who are not paying zakat must be dealt with the government".

\section{DEVELOPING AND PROPOSING MODEL OF ZAKAT MANAGEMENT IN THE MALAKAND DISTRICT}

The following as of figure 1 is our developed and proposed model of the efficient zakat utilization, distribution, and management from the village council to the provincial level in the country which then leads to the federal level zakat department for the zakat funds to the concerned provinces. In the model, we proposed that a 
committee will form at the village level, which collects the data and record of the poor individuals, the committee share this collected data to the tehsil level, which all the village's data and record will be collected, and the tehsil level data will share to the district level of zakat office.

All the district level of data will then share to the provincial zakat and Awqaf department. The provinces then share all these data and records to the federal level department of Zakat and Awqaf. Similarly, the federal department of zakat and awqaf will correctly estimate and analyzed these data and records of the unfortunate individual's and transfer the funds and amount of zakat according to the population of Mustahqeen of zakat. This results in the socioeconomic development of the country as a whole and especially the concerned community and regions of the country.

\section{CONCLUSION}

The zakat is one of the essential factors of Islamic Shariah and imposed by the Allah Almighty on every wealthy Muslims who have the nishab to provide it to the poor community of a society. The zakat is playing a vital role in uplifting the poor segment in most of the developed and developing countries across the globe. This results in the socioeconomic development of society in their respective countries.

In Pakistan, the case is not different from the rest of the developing countries. Zakat can enhance the needs and requirements of the poor community of the society. It not only fulfilled their needs but also developed their socioeconomic status. Zakat can improve the lifestyle of the impoverished population of Malakand district by providing the zakat amount, in which they avail the basic needs of food, shelter, health, and education facilities. Moreover, the other requirements of life, such as marriage expenses and dowry for their children. The current practice of zakat distribution and management in Malakand district is good, but it needs further improvement. The district zakat office provides zakat funds to the poor community of the region. This can help out them from poverty and enhance their lifestyle by approaching their necessities of life.

\section{RECOMMENDATIONS}

The zakat committee is formed in a village council-level and is led by a chairman. We suggest that the local zakat committee shall appoint the members of the village, including the Pesh Imam (person who chairs the mosque of the local village). This is because such a person can efficiently and effectively manage the zakat system in the village council level given he is knowledgeable of Islam.

Moreover, the local committee must collect complete data about the poor population, including, orphans, widows, and others, who have not the ability to fulfill their basic requirements of life. The committee shall identify and analyze the individuals, whether the respective individuals have fulfilled the conditions of Mustahik or not. This is done for good governance practice in the local zakat management.

\section{FUTURE RESEARCH}

This study is an interview-based analysis of the individuals of the two tehsils of Malakand district of KP, Pakistan. Suggestions for future research on the subject domain is a questionnaire, and semi-structured interview both the methods will use for a comprehensive and broad data for 
analyses in the subject domain. Moreover, future research can include who are working in the zakat all the stakeholders of zakat such, collections, distributions, and Mustahik, Muzakki, and the employers management.

Table 1. The List of Questions

\begin{tabular}{|c|c|c|c|}
\hline \multirow{2}{*}{ No. } & \multirow{2}{*}{ Statement } & \multicolumn{2}{|c|}{ Respondents } \\
\hline & & Male & Female \\
\hline Q1 & What do you know about Zakat? & 15 & 13 \\
\hline Q2 & $\begin{array}{l}\text { Do you think Zakat plays a role in the social } \\
\text { welfare of individuals in society? }\end{array}$ & 17 & 11 \\
\hline Q3 & $\begin{array}{l}\text { Do you think the current Zakat system in the } \\
\text { country has fulfilled the needs and requirements } \\
\text { of the poor in society? }\end{array}$ & 19 & 9 \\
\hline Q4 & $\begin{array}{l}\text { What is your perception about Zakat in the } \\
\text { current scenario in your tehsil? }\end{array}$ & 12 & 16 \\
\hline Q5 & $\begin{array}{l}\text { Do you think that Zakat is a suitable option for } \\
\text { the socio-economic development of a country? }\end{array}$ & 10 & 18 \\
\hline Q6 & $\begin{array}{l}\text { What are the issues in the current Zakat system } \\
\text { in your region? }\end{array}$ & 21 & 7 \\
\hline Q7 & $\begin{array}{l}\text { Is Zakat playing their role in the health and } \\
\text { education enhancement of the individual's in } \\
\text { your region? }\end{array}$ & 13 & 15 \\
\hline Q8 & $\begin{array}{l}\text { Is Zakat playing a role in the endowment of the } \\
\text { girls and female in your regions? }\end{array}$ & 14 & 14 \\
\hline Q9 & $\begin{array}{l}\text { Has Zakat enhanced the lifestyle of individual's } \\
\text { in your region? }\end{array}$ & 17 & 11 \\
\hline Q10 & $\begin{array}{l}\text { What are your suggestions for the improvement } \\
\text { of the current Zakat system in your region? }\end{array}$ & 16 & 12 \\
\hline
\end{tabular}

Source: prepared by authors. 


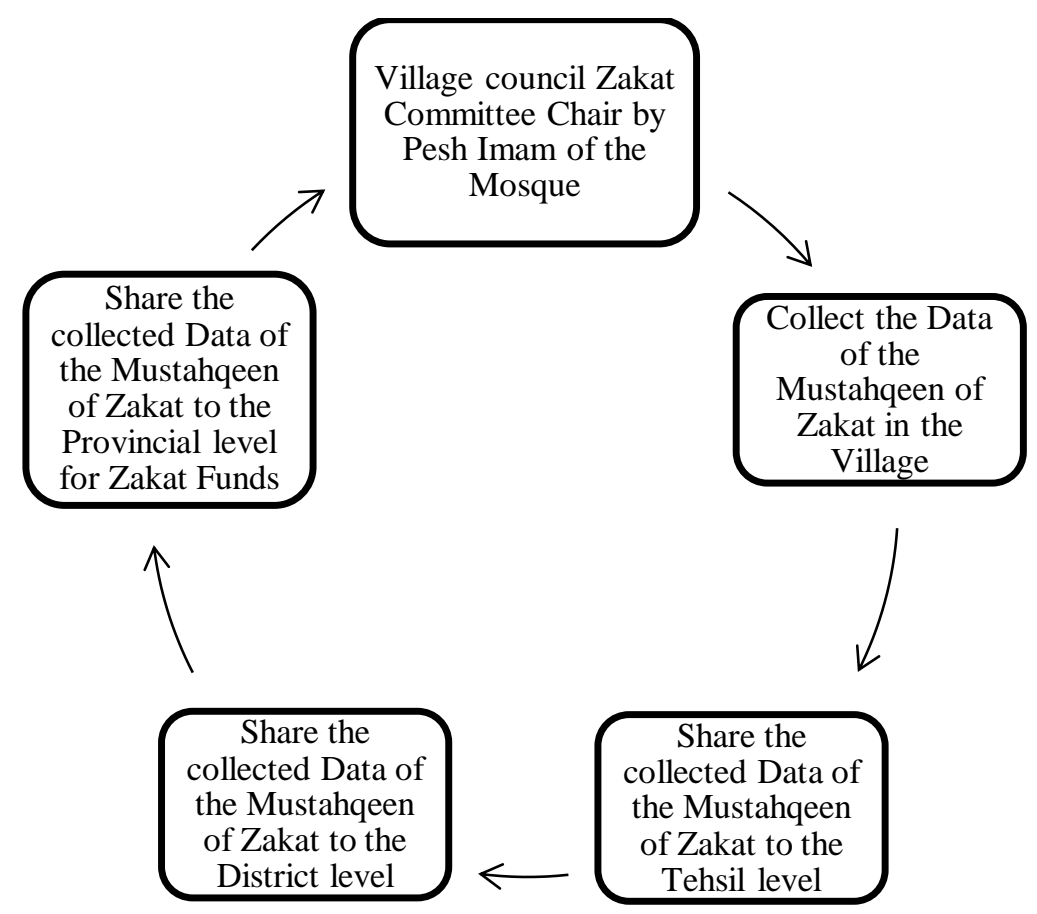

Figure 1. Model of Zakat Management system developed by Authors.

\section{REFERENCES}

Al Haq, M. A., \& Wahab, N. B. A. (2017). Effective Zakat Distribution: Highlighting Few Issues and Gaps in Kedah, Malaysia. Al-Iqtishad: Jurnal Ilmu Ekonomi Syariah, 9(2), 259288.

Alam, N., (2010). Islamic venture philanthropy: A tool for sustainable community development. SSRN Paper series., $1-14$.

Barizah, N., Rahim, A., \& Rahman, A. (2007). A comparative study of zakah and modern taxation. Journal of King Abdulaziz University: Islamic Economics, 20(1), 25-40.

Farooq, M. O., (2008). The challenge of poverty and the poverty of Islamic economics. Journal of Islamic Economics, Banking, and Finance, 4(2), 35-58.

Hassan, M. K., \& Ashraf, A. (2010). An integrated poverty alleviation model combining zakat, awqaf and micro-finance. Paper presented at the Seventh International Conference-The Tawhidic Epistemology: Zakat and Waqf Economy, Bangi, Malaysia.

Hati, S., \& Aida, I. (2014). Antecedents of customers' intention to support Islamic social enterprises in Indonesia The role of socioeconomic status. Asia Pacific Journal of Marketing and Logistics, 707-737.

Kaslam, S., (2009). The advancement of e-zakat for delivering better quality service and enhancing governance sphere of zakat institution in Malaysia. Paper presented at the Proceedings of World Zakat Forum.

Khan, S. N., \& Qutub, S. (2010). The Benazir Income Support programme and the Zakat programme: A political economy analysis of gender. London: 
Overseas Development Institute (ODI), 1-42.

Lubis M., N. I. Y., Yusoff Omar (2011).

Enhancement of zakat distribution management system: Case study in Malaysia. Conference paper, International Islamic University of Malaysia (IIUM), 1-11.

Muliyaningsih, H. D. (2013). Social entrepreneurship in Islamic social welfare system. International Proceedings of Economics Development Research, 73(1), 59.

Sarif, S., \& Kamri, N. (2009). A theoretical discussion of zakat for income generation and its FIQH issues. Shariah Journal, 17(3), 457-500.

Siddiqui, M. (2009). Determinants of poverty in Pakistan: findings from survey Data 2005. European Journal of Social Sciences, 12(1), 52-64.

Statistics, P. B. o. (2017). Province wise provisional results of census2017: Pakistan Bureau of Statistics Islamabad.

Suprayitno, E., Aslam, M., \& Harun, A. (2017). Zakat and SDGs: Impact Zakat on Human Development in the Five States of Malaysia. International Journal of Zakat, 2(1), 61-69.

Toor, I. A., \& Nasar, A. (2003). Zakat as a social safety net: Exploring the impact. Research Report No.53: Social Policy and Development Centre.

Zayas, F. G. d. (2003). The law and institution of zakat: Kuala Lumpur: The Other Press.

Zeb, A., \& Zaman, G. (2014). Assessing the Role of Zakat as a Social Safety Net and problems faced by Zakat Recipients in receiving Zakat Assistance in Pakistan.
Abasyn University Journal of Social Sciences, 7(1), 137-149. 
